\title{
The Effect of Self-Efficacy, Trust and Lifestyle on Intention to Use Digital Financial Transaction Service
}

\author{
Jumardi $^{1}$, Grace T. Pontoh ${ }^{2}$, Nirwana ${ }^{3}$ \\ \{mardhi.kontemplasi@gmail.com ${ }^{1}$,gracetpontoh@gmail.com ${ }^{2}$, nirwana@gmail.com ${ }^{3}$ \} \\ IAI Muhammadiyah Sinjai ${ }^{1}$, Universitas Hasanuddin, Makassar, Indonesia ${ }^{2,3}$
}

\begin{abstract}
The Industrial Revolution 4.0 has produced many advances in the field of technology, one of the latest technologies in finance called the Financial Technology. This study aims to examine and analyze the influences of self-efficacy, trust and lifestyle on the intention to use digital financial transaction services on Go-Pay. The research design was non-experimental and research type was explanatory research or hypothesis testing. Data analysis using exploratory factor analysis and structural equation modeling. This study result indicated that self-efficacy, trust and lifestyle has significant effect on the intention to use digital financial transaction services. These findings propose that behavioral factors such as self-efficacy, trust and lifestyle users can provide a useful understanding and framework to digital financial service providers regarding aspects of services that must be improved in implementing digital financial transaction services, in order to be able to encourage and increase the intensity of e-payment usage.
\end{abstract}

Keywords: Self-efficacy, trust, lifestyle, intention to use, Go-Pay, financial technology.

\section{Introduction}

21st-century people have been in the Industrial Revolution 4.0 era; various advances have been made that affect the pattern of human life. The Industrial Revolution 4.0 is currently the focus of discussion and scientific research in various institutions, including campus scientific spaces. This indicates that the Industrial Revolution has taken over and attracted human life into the advancement of information technology that was developed from time to time. One form of technological innovation today that has a major influence on the flow of global and national markets is "Financial Technology (Fintech)". Advances in information technology have begun to dominate and attract entrepreneurs, especially innovative youth.

Financial Technology (Fintech) is closely related to companies that use modern innovative technology to provide financial services. Arner et al. (2015) said that the fintech evolution was considered as a new market era that integrated technology and finance and would replace traditional financial structures by using new technology. The development of fintech is inseparable from the influence of mobile devices, virtual software, online service personalization, internet, communication technology, and other technological sophistication. People can connect with each other, search for news, shop, and other uses with just one tap. Go-Pay is a digital financial transaction application system from the Go-Jek system, which is currently trending and starting to become an online payment system (e-payment, e-money) [1]. 
Someone will adopt or use the system largely determined by the urge or desire. Both encouragement from within (intrinsic factor) and from outside (extrinsic factor). Desire or intention to behave (behavior intention) is the best prediction of the use of technology by system users. People, both individually and collectively, in adopting an information technology depends on variations in the use of a system, because the use of an information technology-based system can develop individual or organizational performance.

There are several factors that can influence the intention to use or the adoption and acceptance of information technology, especially digital financial transaction services. The intensity to use a system can be influenced by self-efficacy, trust, and lifestyle.

Self-efficacy is an element of the social cognitive theory developed by Bandura (1977; 1982) who put forward theories about individual behavior. Self-efficacy is a factor that determines an individual's intention to behave based on human considerations about his ability to organize and carry out a set of activities needed to obtain planned performances [2].

Other information system acceptance studies also include intrinsic motivational elements such as trust. Bandura (1982) says that trust is part of the social cognitive theory that represents cognitive structures that are developed by individuals after collecting, processing, and synthesizing information, and including individual assessments of various outcomes related to the technology, and have an impact so deep with individual behavior. Trust is one of the important factors that influence the use of cyberspace technology because remote access, of course, every user needs trust. The acceptance of technology by individuals is inseparable from the user's trust in technology [3].

Another factor that can influence the intentions of using technology by individuals is a lifestyle. Lifestyle is a proxy of consumer decision theory, also known as Engel-BlackwellMiniard. This model was first developed in 1968 by Engel, Kollat, and Blackwell. Engel et al. (1994:3) suggested that consumer behavior is a direct action to obtain, consume, and spend products and services, including the decision process that precedes and follows this action. Lifestyle is a lifestyle of someone expressed in their activities, interests, and opinions. This lifestyle can also be reflected in a person's behavior in using a system that has the potential to influence his lifestyle [4].

Based on the above description, it can be formulated: do self-efficacy, trust, and lifestyle influence the intention to use digital financial transaction services? Thus, this study aims to examine and analyze the effect of self-efficacy, trust and lifestyle towards the intention to use digital financial transaction services.

\subsection{Social Cognitive Theory}

The social cognitive theory was developed by Bandura (1977; 1982). Social cognitive theory is based on the proposition that environmental influences such as social pressures or unique situational characteristics, cognitive, and other personal factors, including personality, demographic characteristics, and behavior, influence each other [4]. Self-efficacy, directly and indirectly, influences intention to use. Self-efficacy indirectly influences usage through expectations of expectations, feelings and anxiety [5].

One factor in a social cognitive theory introduced by Bandura (1982), a collection of expectations as the main cognitive pressures that direct behavior is self-efficacy. Self-efficacy factors suggest that a person's judgment about their abilities to organize and carry out the actions needed to achieve the desired performance Self-efficacy is beliefs about a person's ability to perform certain behaviors [3]. 
Another element of social cognitive theory is trust, which represents cognitive structures that are developed by individuals after collecting, processing and synthesizing information, and incorporating individual assessments of various outcomes related to the technology and having such a profound impact on individual behavior [3]. Trust is considered a determining factor in technology acceptance. In addition, trust is also a factor that stimulates purchases through online media services. The social cognitive theory argues that the individual's desire to adopt a technological system is determined by these two constructs, namely self-efficacy and trust.

\subsection{Consumer Decision Model}

Consumer decision models are also known as Engel-Blackwell-Miniard. This consumer decision model was first developed in 1968 by Engel, Kollat, and Blackwell, constantly being revised [4]. Consumer behavior is a direct action to obtain, consume and spend products and services, including the decision process that precedes and follows this action [4]. Consumer behavior covers many fields, namely learning from the process of involvement when individuals or groups choose, buy, use, or sell, products, services, ideas, or experiences to satisfy their needs and desires.

The decision to buy or use something is influenced by three main factors. First, the stimuli obtained from marketing efforts. Second, external environmental variables consisting of culture, social class, the influence of others, family, and situations. Third, individual variables consisting of consumer resources, motivation, knowledge, attitudes, personality, values, and lifestyle [4]. Therefore, the Consumer Decision Model becomes important in this study because it is used to explain the relationship between lifestyle variables with the intention to buy or use products or services, both with complex and simple characteristics.

\subsection{Hypothesis}

Previous studies have found mixed results. Research conducted by Alleyne and Lavine (2013) which suggests that self-efficacy is an important predictor of the intention to use the Enterprise Resource Planning (ERP) system [6]. This is in line with research conducted by Singh and Srivastava (2016) that computer self-efficacy has a significant effect on the intensity of the use of car banking [7]. However, Santoso and Setiawan (2017) examined the relationship of web self-efficacy with the intention to use, suggesting that self-efficacy in using the web (web self-efficacy) did not have a positive effect on the intention to use. Thus, the research hypothesis can be formulated as follows [8].

H1: Self-efficacy has a significant effect on the intention to use digital financial transaction services on Go-Pay.

Previous studies examining the effect of trust on the intention to receive technology show different results. Research conducted by Aklhaq and Ahmed (2013) shows that trust plays an important role in accepting Internet Banking [9]. While research conducted by Singh and Srivastava (2016) suggests that trust does not have a significant effect on the intention to use mobile banking, because trust may seem insignificant because customers consider banks as one of the most trusted institutions. Thus, the research hypothesis can be formulated as follows [7].

H2: Trust has a significant effect on the intention to use digital financial transaction services on Go-Pay. 
The results of research on the relationship of lifestyle with the intensity of the use of technology in previous studies showed positive results. Research conducted by Vandy and Samuel (2011) suggests that lifestyle has a significant effect on the intention to buy [10]. And, Lee et al. (2009) show that consumer lifestyle factors (fashion consciousness, leisure orientation, Internet involvement, and e-shopping preferences) have a direct and indirect effect on consumers' desire to adopt technology products. Thus, the research hypothesis can be formulated as follows [11].

H3: Lifestyle has a significant effect on the intention to use digital financial transaction services on Go-Pay.

\section{Research Methodology}

The approach used in this research is a quantitative approach. The research design is nonexperimental, and the type of research is explanatory research. This study aims to test the hypothesis (hypothesis testing) that explains the effect of independent variables on the dependent. Research hypotheses are developed based on theories related to the research topic and then tested based on appropriate analytical techniques. The nature of this study is a correlation, which aims to find important variables related to problems in research. Before measuring the strong relationship and influence between the independent variable and the dependent variable, each variable is defined and measured based on its proxies. The research environment is the real environment (field setting) with the unit of analysis being the Go-Jek service users who use the Go-Pay transaction service.

The population in this study is the people of Makassar City who use the Go-Pay application in their transaction payment system. The data collection method used in this study was a questionnaire by distributing 400 questionnaires to respondents. Deployment techniques are carried out in various ways, namely to meet directly with Go-Pay user respondents, dissemination through Go-Jek and Go-Car conductors, and dissemination through several GoJek partners.

There are five variables and operational definitions in this study, namely:

1) An intention for someone to do a certain behavior, someone will do a behavior if you have the desire or interest or intention to do it.

2) Self-efficacy is a person's belief about their ability to organize and carry out the necessary actions using the Go-Pay financial transaction service system to achieve the intended use.

3) Trust is the extent to which a person believes that using a Go-Pay financial transaction service will not hurt most economic interactions where uncertainty arises.

4) Lifestyle is the lifestyle of a person expressed in his activities, interests and opinions in allocating his time and money in various daily activities using the Go-Pay financial transaction service.

Research instruments in the form of a questionnaire. The questionnaire contains statements from indicators of all research variables using a Likert scale with five answer choices, namely $1=$ strongly disagree to $5=$ strongly agree which is adopted and developed from several references, namely self-confidence (Compeau and Higgins, 1995), trust (Pavlou, 2003), lifestyle (Lee et al., 2009), and intentions to use (Davis, 1989) [5], [11]-[13].

The data analysis technique used in this study is Structural Equation Modeling (SEM) with the IBM SPSS Statistical Analysis of Moment Structure (AMOS) version 21 program. 
The data analysis used in this study is descriptive statistics, data quality test, Structural Equation Modeling analysis and goodness of fit, and hypothesis testing.

\section{Result and Discussion}

\subsection{Descriptive Statistics}

The questionnaire was distributed as many as 400 questionnaires, six respondents who did not return the questionnaire, and 15 questionnaires that were incomplete. Thus from the questionnaire distributed to 400 respondents, only 379 returned, and complete questionnaires could be processed further.

Demographics based on calamine showed that female respondents were 249 people or $66 \%$ more than male respondents, which were 130 people or $34 \%$. This shows that Go-Pay users are dominated by users who are female. Based on age, it shows that Go-Pay users are in the productive age, that is, ranging from 26-35 years as many as 177 people (47\%) and 17-25 years as many as 121 people (32\%), than those aged 36-45 years as many as 58 people ( $15 \%)$ and those aged $>45$ years are 23 people $(6 \%)$. Based on the education level of respondents shows that Go-Pay users are dominated by users who have Diploma / Strata One level (D3 / S1) as many as 231 people (61\%), then followed by high school as many as 125 people (33\%), junior high as many as nine people $(2 \%)$, and Others 14 people $(4 \%)$. Based on the experience of using Go-Pay shows that Go-Pay users are dominated by respondents who have experience of using more than ten times, namely 227 people $(60 \%)$, then using $1-5$ times by 81 people (21\%) and using 5-10 times as many as 70 people (18\%).

\subsection{Data Analysis}

A validity test is done by using confirmatory factor analysis on each latent variable through the AMOS 21 program. This study uses 379 samples, then the factor loading of the EFA (Exploratory Factor Analysis) must reach 0.30 [14]. The results show that the loading value of the measured variable of each construct is greater than 0.30 . Reliability testing uses construct reliability with a cut-off value of at least 0.70 [14]. A construct is said to be reliable if it shows the construct reliability value of each construct is greater than 0.70 . The results show the CR value of each construct is greater than 0.70 , and the measured factor loading value of each construct is greater than 0.30 . Thus, all constructs used in this study are valid and reliable.

The results of the model fitness test (goodness-of-fit test) can be seen in Table 1. Table 1 shows that there are two poor indexes of conformity, namely chi-square and significance probability, but the CMIN/DF index, GFI, RMSEA, RMR, CFI, TLI, and NFI show good grades. Thus, the model in this study can be said to be fit (fit), which means there is a match between the model and the data.

Table 1. Criteria for The Goodness of Fit Index Model

\begin{tabular}{cccc}
\hline Good of Fit Index & Cut-off Value & Estimated Results & Model Evaluation \\
\hline Chi-Square & Expected to be lower & 374.055 & Marginal \\
Probability & $\geq 0.05$ & 0.000 & Marginal \\
\hline
\end{tabular}




\begin{tabular}{cccl}
\hline CMIN/DF & $\leq 2$ & 1.928 & Good Fit \\
GFI & $\geq 0.90$ & 0.930 & Good Fit \\
RMSEA & $\leq 0.08$ & 0.050 & Good Fit \\
RMR & $\leq 0.05$ & 0.025 & Good Fit \\
CFI & $\geq 0.90$ & 0.948 & Good Fit \\
TLI & $\geq 0.90$ & 0.920 & Good Fit \\
NFI & $\geq 0.90$ & 0.901 & Good Git \\
\hline
\end{tabular}

Source: Results of data processing with AMOS 21

The basis of significance used in testing hypotheses is to look at the p-value; if the pvalue is less than 0.05 , then the relationship between variables is significant. Table 2 provides output regression weights for testing the model.

Table 2. Results of the Regression Weights Hypothesis

\begin{tabular}{|c|c|c|c|c|c|}
\hline & Variable & Standardize & C.R & p-value & Information \\
\hline $\begin{array}{c}\text { Self- } \\
\text { Efficacy }\end{array}$ & $\rightarrow \quad$ Intention to Use & 0.233 & 3.518 & $* * *$ & Significant \\
\hline Trust & $\rightarrow \quad$ Intention to Use & 0.278 & 2.194 & 0.028 & Significant \\
\hline Lifestyle & Intention to Use & 0.743 & 3.975 & $* * *$ & Significant \\
\hline
\end{tabular}

Source: Results of data processing with AMOS 21

\subsubsection{Testing the Effect of Self-Efficacy on the Intention to Use Digital Financial Transaction Services on Go-Pay}

The results of testing the first hypothesis showed that the relationship of self-efficacy variables (X1) with the intention to use (Y) showed a path coefficient of 0.233 with a cr value of 3.518. This value is greater than the table (1.967), and the probability level is below 0.05 $(0.00<0.05)$. This result indicates that the variable intention to use digital financial transaction services on Go-Pay is positively influenced by the variable self-efficacy of $23.3 \%$. This means, the higher the individual's self-efficacy, the higher the intention to use digital financial transaction services in Go-Pay.

This research supports social cognitive theory, which states that someone who has selfefficacy about his ability to behave or to do a certain behavior [3]. Self-efficacy in skills, knowledge, mature considerations, independence, and the ability to organize the behavior of the user will be able to face and resolve any obstacles and challenges to the adoption of technology, especially transaction services on Go-Pay. This indicates that the user's selfefficacy plays an important role in financial transaction services in Go-Pay in influencing intention to use.

This study is in line with the research of Singh and Srivastava (2018) and Alleyne and Lavine (2013) [6], [7]. However, this study does not support what has been done by Santoso and Setiawan (2017). Self-efficacy is an important predictor of technology service providers because what is used, how often it is used, where and when it is used will depend on the level of user ability regarding these matters. Self-efficacy will influence the decision to use technology. If the user has higher self-efficacy, he will be better in making decisions; he will be more efficient and more precise in processing and using technology services better. Digital service users will use various methods in evaluating the technology services offered. Users 
who have higher self-efficacy will be aware of the importance of technology services. Furthermore, users will become more aware of the value provided by the service and result in the formation of an intention to purchase and use the technology services offered by the service provider [8].

\subsubsection{Testing the Effect of Trust on Intention to Use Digital Financial Transaction Services on Go-Pay}

The results of the second hypothesis testing showed that the relationship of the trust variable (X2) with the intention to use (Y) showed a path coefficient of 0.278 with a t value of 2.194. This value is greater than t table (1.967), and the probability level is below $0.05(0.028$ $<0.05)$. These results indicate that trust has a significant effect on the intention to use digital financial transaction services on Go-Pay, or in other words, the intensity of the use of Go-Pay is affected by the user confidence variable by $27.8 \%$. This means, the higher the level of individual trust in digital financial transaction service systems on Go-Pay, the higher the perceived intention to use.

This research supports the social cognitive theory, which is an intrinsic factor that determines individual behavior [3]. This study also supports the research of Akhlaq and Ahmed (2013) and Cheminggui and Lallouna (2013) [9], [15]. But this study is not in line with research conducted by and Singh and Srivastava (2018). Trust must be considered as one of the most important user attributes. User trust is very important in facilitating long-term customer relationships as a series of transactions take place, and if consumers experience positive trust, then that trust will tend to continue. The trust of users or potential users is very important for every technology service provider so that they want to use the financial transaction services offered without hesitation. Without strong trust, it will be difficult to expect any intention or intention from users to conduct financial transactions through Go-Pay. In addition, maintaining the trust of users will make them loyal to the use of financial transaction services offered [7].

\subsubsection{Testing the Effect of Lifestyle Intention to Use Digital Financial Transaction Services on Go-Pay.}

The results of the third hypothesis testing showed that the relationship between lifestyle variables (X3) and intention to use (Y) showed a path coefficient of 0.743 with a t value of 3.975 This value was greater than t table (1.967) and a probability level below $0.05(0.00<$ $0.05)$. The intention to use (Y) variable is positively influenced by lifestyle variables (X3) of $74.3 \%$. These results indicate that lifestyle has a significant effect on the intention to use digital financial transaction services on Go-Pay.

This study supports the consumer decision theory (consumer decision model), which states that purchasing decisions are influenced by three main factors, one of which is an individual variable consisting of consumer resources, motivation, knowledge, attitudes, personality, values, and lifestyle [4]. This study also corroborates the research conducted by Vandy and Samuel (2011) and Lee et al. (2009). Lifestyle (lifestyle) is seen as one of the most important elements for individuals in determining their interests or opinions on a product in spending their money and allocating their time. By setting clear and specific targets, it is expected that people's desire to use financial transaction services on Go-Pay can increase, so the number of transactions that use Go-Pay (non-cash) also increases [10], [11].

People's decision to use digital financial transaction services is inseparable from the lifestyle of those who want to use products that are considered more useful and have better quality. The current needs of the community have led to a lifestyle that will determine the 
choices of goods and services; then it will make a person become more consumptive. Thus, in an effort to increase people's intention to use digital financial transaction services on Go-Pay in non-cash transactions, it is necessary to look at the lifestyle of a community. This is because, practically, the lifestyle profile of the community is an important determinant for service providers to streamline their service programs, because, with a lifestyle profile map, consumers of service providers can understand the characteristics of their target market.

\section{Conclusion}

This research proves the factors that influence one's intention to use a technology-based system, especially technology, in the form of digital financial transaction services. The higher the self-efficacy a person has, the higher the intention to use that a person expects to use technology. These results support the social cognitive theory. Then, the higher the trust owned by someone, the higher the intention to use perceived by someone in the use of technology. These results support the social cognitive theory that represents cognitive structures developed by individuals. And, the more specific lifestyle of an individual, the higher the intention to use felt by someone in the use of a technology that is considered a form of lifestyle that is expressed in their activities, interests, and opinions. These results support the consumer decision theory or Consumer decision model.

To refine the policy, for providers and developers of the Financial Technology (Fintech) system, Go-Pay in particular and similar companies that provide similar financial services, in general, must pay more attention to the behavior of individuals as users, so that users have an intense intention to use digital financial transaction services provided in their daily activities. Go-Pay parties or policymakers related to the provision of digital financial transaction services in increasing the intention of service users, to pay attention and improve several factors.

The user confidence factor that is targeted towards the value of the service provided. Because service users will use various methods in evaluating the technology services offered. The trust factor for the financial transaction services offered. Because maintaining the trust of users will make them loyal to continuously use the financial transaction services provided. The lifestyle factor of the user community, because the community's decision to use digital financial transaction services is inseparable from the lifestyle of those who want to use products that are considered more useful and have a better quality of citizens. Therefore, the provider needs to set clear and specific targets in accordance with the wishes of the public in using digital financial transaction services on Go-Pay, so that the number of users who transact through Go-Pay also increases.

This study has limitations that can affect the results and need to be disclosed so as not to provide a misleading interpretation for the reader, namely the questionnaire distributed to respondents is inseparable from the possibility of perception bias caused by several things including the questionnaire that is entrusted to the driver Go-Jek, Go- Car and Go-Jek's partners could not be known with certainty whether it was the right person to complete the questionnaire. In addition, this study only emphasizes intrinsic factors, namely self-efficacy, trust, pleasure, and lifestyle.

For that, further research needs to get a database of user companies that have provided similar technology system applications. Such data is difficult to obtain from software provider companies because it is a company secret. Lifestyle factors have the greatest influence on the intention to use digital financial transaction services, so researchers can then consider testing 
any indicator of the style variable. Future studies can also consider adding independent variables, both intrinsic and extrinsic factors. In addition to this, further research can also use other behavioral theories, such as a combination of Technology Acceptance Model (TAM), Unified Theory of Acceptance \& Use of Technology (UTAUT) or Attribution Theory.

\section{References}

[1] Arner. D. W, Barberis.J, and Buckley. R. P.: The evolution of Fintech: A new post-crisis paradigm. Geo. J. Int'l L. vol. 47, pp. 1271 (2015).

[2] Bandura. A.: Self-efficacy: toward a unifying theory of behavioral change. Psychological review. vol. 84, no. 2, pp. 191. (1977).

[3] Bandura. A.: Self-efficacy mechanism in human agency. American psychologist. vol. 37, no. 2, pp. $122(1982)$.

[4] Engel. J. F, Blackwell. R. D, and Miniard. P. W.: Perilaku Konsumen Jilid 1. Jakarta: Binarupa Aksara (1994).

[5] Compeau. D. R and Higgins. C. A.: Computer self-efficacy: Development of a measure and initial test. MIS quarterly. pp. 189-211 (1995).

[6] Alleyne. P and Lavine. M.: Factors influencing accountants' behavioural intentions to use and actual usage of enterprise resource planning systems in a global development agency. Journal of Financial Reporting \& Accounting. vol. 11, no. 2, pp. 179-200 (2013).

[7] Singh. S and Srivastava. R. K.: Predicting the intention to use mobile banking in India. International Journal of Bank Marketing (2018).

[8] Santoso. W. N and Setiawan. D.: Faktor-Faktor yang Mempengaruhi Niat Penggunaan Approweb oleh Account Representative Direktorat Jenderal Pajak. Jurnal Akuntansi. vol. 21, no. 2, pp. 232 252 (2017).

[9] Akhlaq. A and Ahmed. E.: The effect of motivation on trust in the acceptance of internet banking in a low income country.: International journal of bank marketing. pp. 115-125 (2013).

[10] Vandy. K and Samuel. P. A.: MGaya Hidup, Persepsi, dan Intention to Buy: Studi Perilaku Mahasiswa Terhadap Pemilihan Jasa Perbankan. Jurnal Prosiding Swiss German University (2011).

[11] Lee. H.J, H. Lim, Jolly. L. D, and Lee. J.: Consumer lifestyles and adoption of high-technology products: a case of South Korea. Journal of International Consumer Marketing. vol. 21, no. 2, pp. 153-167 (2009).

[12] Pavlou. P. A.: Consumer acceptance of electronic commerce: Integrating trust and risk with the technology acceptance model. International journal of electronic commerce. vol. 7, no. 3, pp. 101134 (2003).

[13] Davis. F. D.: Perceived usefulness, perceived ease of use, and user acceptance of information technology. MIS quarterly. pp. 319-340 (1989).

[14] Hair. J. F., Black. W. C., Babin. B. J., and Anderson. R. E.: Multivariate data analysis, 6th ed. Upper Saddle River, New Jersey, USA: Prentice-Hall, International Inc (2006).

[15] Chemingui. H,:: Resistance, motivations, trust and intention to use mobile financial services. International Journal of Bank Marketing. pp. 574-592 (2013). 